\title{
51. Behavioral Adaptation of Paramecium caudatum to Environmental Temperature
}

\author{
The Effect of Cell Density
}

\author{
By Yasuo NaKaoka, Hisayasu Tokui, Yoshihiko Gion, \\ Shigeru Inoue, and Fumio Oosawa \\ Department of Biophysical Engineering, Osaka University, \\ Toyonaka, Osaka 560 \\ (Communicated by Masao Kotani, M. J. A., Sept. 13, 1982)
}

Paramecium is a single cell organism which swims by beating a large number of cilia on its cell surface. When put in a temperature gradient, paramecium cells accumulate in a region of a specific temperature at which they were cultured. ${ }^{1)}$ The cells cultured at $25^{\circ} \mathrm{C}$ gather to $25^{\circ} \mathrm{C}$ and those cultured at $30^{\circ} \mathrm{C}$ gather to $30^{\circ} \mathrm{C}$. In a vessel, of which one end is fixed at a temperature $\mathrm{T}_{1}$ higher than the culture temperature $T_{0}$ and the other end at $T_{2}$ lower than $T_{0}$, cells swimming toward the region of $\mathrm{T}_{0}$ from both sides show a smaller frequency of discontinuous changes of swimming direction than those swimming away from the region of $\mathrm{T}_{0}$. Such behaviors result in accumulation of the cells in the region of $\mathrm{T}_{0}{ }^{2), 3)}$ The cells swimming in a temperature gradient sense a change of the environmental temperature with time. The behaviors of the cells in a temperature gradient can be explained based on their responses to the temperature change with time. ${ }^{2), 3)}$

Thus, paramecium cells retain some memory of the culture temperature and regulate the response to the temperature change to cause accumulation at the culture temperature. Such memory of the culture temperature is expected to be established in the process of adaptation to the environmental temperature. In this work, the process of adaptation has been followed by observing the swimming behaviors of paramecium cells after transferring them from the culture temperature to a different temperature. An effect of the cell density on this process has been found.

Specimen of Paramecium caudatum (Ksy 1 of mating type V) have been kindly supplied by Professor Hiwatashi of Tohoku University. They were cultured in a hay infusion containing $2-3 \mathrm{mM}$ Tris-maleate buffer of $\mathrm{pH} 7.0$ with Aerobacter in a water bath kept at a constant temperature.

In the first experiment, paramecium cells cultured at $25^{\circ} \mathrm{C}$ for a few days were transferred into a vessel kept at $30^{\circ} \mathrm{C}$. As shown 
in Fig. 1, immediately after the transfer, the cells showed a very large frequency of directional changes because of the sudden temperature change. As mentioned already, such an increase of the frequency is an important response for the cells to accumulate at the culture temperature in a temperature gradient. A few minutes after the transfer to $30^{\circ} \mathrm{C}$, however, the frequency decreased and attained a stationary value which was maintained for about $40 \mathrm{~min}$. Then, the frequency decreased again to a final value.

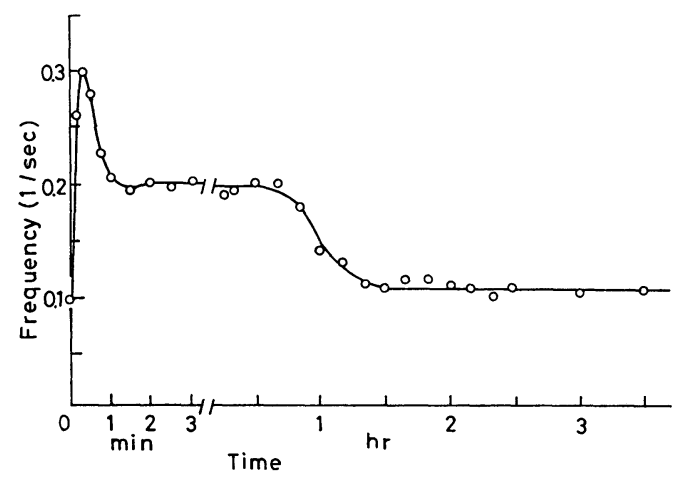

Fig. 1. The change of the frequency of directional changes after paramecium cells cultured at $25^{\circ} \mathrm{C}$ were transferred to $30^{\circ} \mathrm{C}$. The transient response immediately after the transfer and the change of the frequency in the stationary or final state are shown in different time scales.

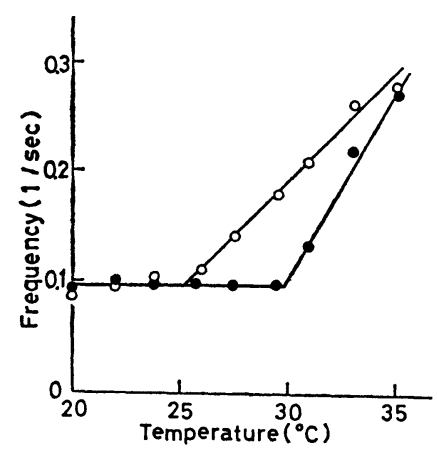

Fig. 2. The relation between the frequency of directional changes in the stationary state and the temperatures. Paramecium cells were cultured at $25^{\circ} \mathrm{C}(\bigcirc)$ and $30^{\circ} \mathrm{C}$ (๑), respectively.

Similar behaviors, a transient increase of the frequency followed by a decrease to a stationary value, were observed when the cells were transferred from $25^{\circ} \mathrm{C}$ to different temperatures $\mathrm{T}$. The frequency in the stationary state depended on $\mathrm{T}$ to which the cells were transferred. As shown in Fig. 2, the frequency was low when $\mathrm{T} \leq 25^{\circ} \mathrm{C}$ and increased with rising temperature when $\mathrm{T}>25^{\circ} \mathrm{C}$. In the case of the cells cultured at $30^{\circ} \mathrm{C}$, the frequency in the stationary 
state was low when $\mathrm{T} \leq 30^{\circ} \mathrm{C}$ and increased when $\mathrm{T}>30^{\circ} \mathrm{C}$. The influence of the culture temperature is preserved in the relation between the frequency of directional changes and the temperature $\mathrm{T}$.

Fig. 2 indicates that in the stationary state the frequency of directional changes of paramecium cells cultured at $25^{\circ} \mathrm{C}$ and then transferred to $30^{\circ} \mathrm{C}$ is larger than that of the cells cultured at $30^{\circ} \mathrm{C}$. However, as shown in Fig. 1, the frequency in the stationary state began to decrease again about $40 \mathrm{~min}$ after the transfer to $30^{\circ} \mathrm{C}$. The final value of the frequency was equal to that of the cells cultured at $30^{\circ} \mathrm{C}$ for a few days.

If, after the decrease of the frequency to the final value, the cells were returned to $25^{\circ} \mathrm{C}$, their frequency showed a transient increase. This means that the cells adapted to the new temperature, $30^{\circ} \mathrm{C}$. Actually, they could accumulate at $30^{\circ} \mathrm{C}$ if put in a temperature gradient. The experiment in Table I shows the correlation between the frequency in the stationary or final state and the transient response to sudden temperature changes. At various times after the transfer of the cells from $25^{\circ} \mathrm{C}$ to $30^{\circ} \mathrm{C}$ (column 1 of Table I), the frequency of directional changes was measured at $30^{\circ} \mathrm{C}$ (column 2) . Then, a temperature change from $30^{\circ} \mathrm{C}$ to $25^{\circ} \mathrm{C}$ was given and the transient response in the frequency was observed (column 3). After a few minutes, the temperature was returned to $30^{\circ} \mathrm{C}$ and the transient response was observed again (column 4). The switching of the transient response (columns 3 and 4 ) took place in parallel to the decrease of the frequency in the stationary state to the final value (column 2).

In the course of the above experiment, it was found that the time necessary for establishment of adaptation to a new temperature depended on the cell density (the number of cells per unit volume). As shown in Fig. 3a, the decrease of the frequency in the stationary state to the final value occurred faster at higher cell densities. The

Table I. Changes of the frequency in the stationary or final state and the transient response after transfer of paramecium cells from $25^{\circ} \mathrm{C}$ to $30^{\circ} \mathrm{C}$

\begin{tabular}{cccc}
\hline \multirow{2}{*}{$\begin{array}{c}\text { Time after } \\
\text { transfer (hr) }\end{array}$} & $\begin{array}{c}\text { Stationary or final } \\
\text { frequency at } 30^{\circ} \mathrm{C} \\
\left(\mathrm{sec}^{-1}\right)\end{array}$ & \multicolumn{2}{c}{$\begin{array}{c}\text { Transient changes } \\
\text { of frequency }\end{array}$} \\
\cline { 3 - 4 } & 0.20 & $-30^{\circ} \mathrm{C}$ to $25^{\circ} \mathrm{C}$ & $25^{\circ} \mathrm{C} \mathrm{to} 30^{\circ} \mathrm{C}$ \\
\hline 0.5 & 0.20 & + & + \\
1 & 0.12 & + & 0 \\
24 & 0.10 & + & -
\end{tabular}

The procedure of the experiment is described in the text. + , increase of frequency; - , decrease of frequency; 0 , no change of frequency. 
time at the midpoint of the frequency decrease, i.e., the half time $\tau$ was inversely proportional to the square root of the cell density, as plotted in Fig. 3b.

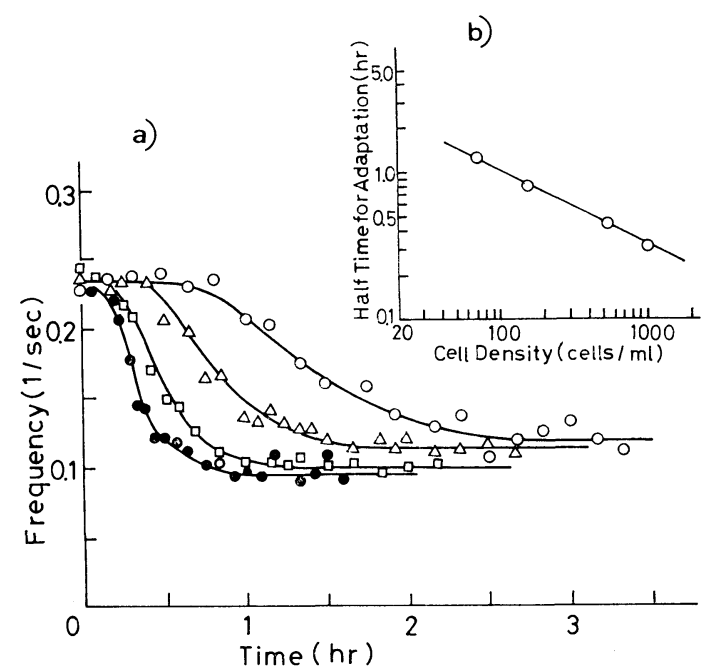

Fig. 3. a: The effect of the cell density on the process of adaptation. Suspensions of paramecium cells of different cell densities in the same medium were prepared from a culture at $25^{\circ} \mathrm{C}$ and transferred to $30^{\circ} \mathrm{C}$ at time zero. The cell density in number $/ \mathrm{ml}$ was $75(\mathrm{O})$, $150(\triangle), 550(\square)$ and $1000(\bullet)$, respectively. (The initial transient response is not shown in this figure.) $b$ : The relation between the half time of adaptation and the cell density obtained from the dzśa of (a).

A possible mechanism of facilitation of adaptation by high cell density may be that the cells transferred to a new temperature would release to the medium some substance which promotes adaptation. Therefore, the effect of the medium was examined. A suspension of paramecium cells cultured at $30^{\circ} \mathrm{C}$ was transferred to $25^{\circ} \mathrm{C}$. After incubation at the new temperature $25^{\circ} \mathrm{C}$ for $1-2 \mathrm{hrs}$, the suspension was gently centrifuged to remove the cells. To the supernatant obtained, other paramecium cells cultured at $25^{\circ} \mathrm{C}$ were added and the mixture was transferred to $30^{\circ} \mathrm{C}$. Immediately after the transfer, the frequency of directional changes of the cells began to decrease and within $30 \mathrm{~min}$, it attained a final value which corresponded to that of the cells cultured at $30^{\circ} \mathrm{C}$. On the other hand, the supernatant obtained from a suspension incubated at $25^{\circ} \mathrm{C}$ for $4 \mathrm{hrs}$ had no effect to promote adaptation of other cells. This result suggests that the effective substance released to the medium has a limited life time and the cells stop to release it after establishment of adaptation. 
The same supernatant was equally effective to promote adaptation of other cells to any new temperature in a range from $20^{\circ} \mathrm{C}$ to $30^{\circ} \mathrm{C}$, and the supernatant obtained from suspensions of the cells transferred to various temperatures showed the same effect to promote adaptation of other cells.

In order to describe the process of adaptation, let us denote the total number of cells as $N$ and the number of cells which have adapted to a new temperature as $n(t)$, a function of time $t$. After the transfer to a new temperature, each cell releases a substance $X$ the concentration of which, $x$, increases in proportion to the number of cells which have not yet adapted, $N-n$. The adaptation of each cell is facilitated by $X$, so that the rate of increase of the number $n$ is proportional to the product of $x$ and $N-n$. That is,

$$
\begin{aligned}
& d x / d t=\alpha(N-n) \\
& d n / d t=\beta x(N-n)
\end{aligned}
$$

where $\alpha$ and $\beta$ are constants. The integration of these equations with the initial condition, $n=0, x=0$ at $t=0$, gives

$$
\ln ((\sqrt{ } N+\sqrt{n}) /(\sqrt{N}-\sqrt{n}))=\sqrt{2 \alpha \beta} \sqrt{ } N t
$$

Therefore, if $\tau$ is defined by $n(\tau)=N / 2$,

$$
\tau=\gamma / \sqrt{\alpha \beta} \sqrt{N}
$$

which agrees with the result of Fig. 3b. $\quad(\gamma=\sqrt{2} \ln (\sqrt{2}+1)$. $)$ The function $n(t)$ of (3) can express approximately the result of Fig. 3a.

Thus, it is very likely that some substance is released from paramecium cells to the medium in the course of adaptation and works as a kind of catalyst for adaptation. The fractionation of an effective component from the medium is not yet successful.

The adaptation of paramecium cells to the environmental temperature was exhibited by the frequency of directional changes which is regulated by fluctuation of the membrane potential.4),5) Therefore, the observed adaptation may be primarily associated with some structural change in the membrane, and the released substance may be a catalyst for such a structural change.

\section{References}

1) Mendelssohn, M. (1895): Pflüger's Arch. Ges. Physiol., 60, 1.

2) Nakaoka, Y., and Oosawa, F. (1977): J. Protozoology, 24, 575.

3) Oosawa, F., and Nakaoka, Y. (1977): J. Theor. Biol., 66, 747.

4) Majima, T. (1980): Biophys. Chem., 11, 101.

5) Naitoh, Y., and Eckert, R. (1974): Cilia and Flagella (ed. by Sleigh, M.). Acad. Press, New York, 305 pp. 